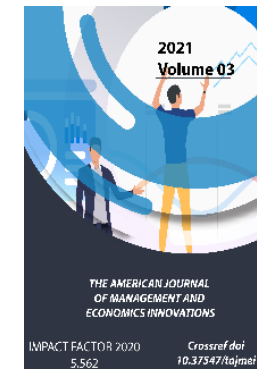

Journal Website: https://theamericanjou rnals.com/index.php/ta jmei

Copyright: Original content from this work may be used under the terms of the creative commons attributes 4.0 licence.

\section{The Issue Of Modern Strategic Management In Enterprises Or Firms}

\author{
Rustam Tokhirov \\ Lecturer, Kokand University, Uzbekistan
}

Abdulaziz Abdurakhimjanov

Student, Kokand University, Uzbekistan, Kokand City

\title{
ABSTRACT
}

Strategic management is a management function focused on long-term goals and actions, as well as a set of long-term measures and approaches aimed at improving the vitality and strength of an individual or a group of individuals in relation to competitors. Strategy formulation is the direction of action and its clear tool is a key part of management and an important sign of good governance.

\section{KEYWORDS}

Strategic management is the continuous planning, monitoring, analysis and evaluation of all the needs that an organization needs to accomplish its goals and objectives.

\section{INTRODUCTION}

Strategic management typically assumes financial and non-financial benefits. Strategic management sets the direction for the organization and its employees.

Unlike once-implemented strategic plans, effective strategic management constantly plans, monitors, and tests an organization's performance, resulting in increased operational efficiency, market share, and profitability.
Having a defined process for managing an institutional strategy will help organizations make logical decisions and quickly develop new goals to adapt to evolving technologies, market and business conditions. Thus, strategic management helps an organization to have a competitive advantage, improve market share, and plan for the future.

The essence of strategic management is to develop a long-term strategy necessary to win 
the competition, to implement management on a real scale of time. The corporation's developed strategy becomes the business plans of the current production, which must then be put into practice. Strategic planning can predict a firm's or organization's 10-15 year plans when it comes to averaging.

Advantages of strategic management:

Evaluate the strategic direction of the enterprise;

Develop an action plan for development and work accordingly;

Becoming a strong competitive firm;

Ability to see far.

\section{METHODS}

Through the scientific article, research methods such as comprehensive study of strategic management, analysis, study of forces and obstacles driving the production enterprise (gas station), observation, SWOTanalysis, targeted development were used.

\section{RESULT}

At present, the people of our country do not pay attention to electric cars. The reason is that the conditions for electric cars in our country are not enough. However, as time progresses, so do techniques and technologies. It is obvious that electric cars are the car of the future.

Advantages of electric cars over cars:

Fuel is not needed at all, economical;

Prevents air pollution;
It is possible to recharge the battery at home;

There is a possibility of energy recuperation.

Disadvantages:

The efficiency is low;

The inability of electric vehicles to travel long distances (temporary problem).

If we take a certain gas station. Nowadays, with the development of modern times, the range of cars is growing. On average, if we take a 10-year strategic plan, there is an assumption that cars will be replaced by electric cars. Well, will the gas stations be empty after the electric cars enter our country? In order to prevent gas stations from becoming empty and to prevent unemployment, it is necessary to install equipment to support electric vehicles inside gas stations. Unemployment will be prevented and gas stations will be able to resume operations.

SWOT analysis of the implementation of strategic management at a

manufacturing enterprise (gas station) 


\begin{tabular}{|c|c|}
\hline Strengths & Weaknesses \\
\hline$\bullet \quad \begin{array}{c}\text { Enterprise development; } \\
\text { Act to achieve a specific goal; }\end{array}$ & $\begin{array}{c}\bullet \text { The development of new modern } \\
\text { technologies does not meet the demand }\end{array}$ \\
\hline $\begin{array}{c}\text { Opportunities } \\
\text { electric vehicles on the territory of Uzbekistan; } \\
\text { There is a population interested } \\
\text { in electric vehicles; }\end{array}$ & $\begin{array}{c}\text { Threats } \\
\text { mobile phones into the territory of Uzbekistan; } \\
\text { Production of self-supporting } \\
\text { vehicles }\end{array}$ \\
\hline
\end{tabular}

Feedback: A common axiom in management is that a qualified manager can manage any job. Most managers are more generalists than professionals, however, many successful managers start their careers in specialist roles. Successful managers lead their work in leading brigades, divisions, divisions, and companies and develop their companies based on strategies and plans. Through strategic management, the future of the company is considered. A manager who thinks about the future will keep pace with the times. That is, what is the current demand and why will the demand increase in the future. Through SVOT analysis, we can see that our country also needs electric cars, and there are all the conditions for this. It's just a matter of supporting it. After some time, this will be resolved.

The manager, who has been working through the strategy, thinks the company will prosper. There are also managers who do not take their work seriously. Well, a manager who meets the requirements of the time and knows every field develops a company strategy, thereby developing himself and the company he works for.

Conclusion: Strategic management is nothing more than planning for predictable and unforeseen situations. This applies to both small and large organizations, as even the smallest organization faces competition, and by developing and implementing appropriate strategies, they can gain a sustainable competitive advantage. It is a way to set strategic goals and continue on the path to achieving them. It has to do with decisionmaking and implementation about the future activities of the organization. This helps us determine in which direction the organization is moving.

Strategic management is an ongoing process. Strategic planning is followed by tactical and then operational planning.

\section{CONCLUSION}

The first process of strategic management is to analyze the organizational environment. Many studies have shown that firms engaged in strategic management are more profitable and successful than those without the benefits of strategic planning and strategic management. Firms control the future when they engage in forward planning and careful evaluation of their priorities. 
A key aspect of strategic management is that firms 'ability to solve problems and prevent them is improved through strategic management. Helps firms make changes and communicate to their employees the need for better change. Strategic management helps to establish order and discipline in the company's activities, both internally and externally.

\section{REFERENCES}

1. Development strategy of Uzbekistan. Civil Society (Methodological Manual) I Tashkent: Info Capital Group Publishing House, 2019.

2. Gulyamov S.S., Ayupov R.H. Fundamentals of digital economy and e-commerce. Tashkent: TMI, Economy and Finance Publishing House, 2020.

3. Mulaydinov F., Butaboev M. The concept and essence of the digital economy. Action Strategy of the Republic of Uzbekistan: Macroeconomic Stability, Investment Activity and Prospects for Innovative Development [Electronic Collection]. - Tashkent: Special issue of the scientific electronic journal Economy and Innovative Technologies, 2019.

4. Nishanbaeva E.Z. Principles of civil society and social partnership. Tashkent, Sharq, 2015.

5. Baltabaeva G.R. and others. Prospects for the development of e-business in Uzbekistan. Tashkent, Format Polygraph Publishing House, 2016.

6. Schumpeter I. The theory of economic development: studies of entrepreneurial profit, capital, credit, interest and the cycle of conjuncture. Moscow, Progress, 1982.

7. Xasanov, I. M. (2019). Problems of employment in Uzbekistan. Образование и наука в России и за рубежом, (16), 156158.

8. Baltabaeva G.R. and others. Directions of innovative development in small business and entrepreneurship. Tashkent, Science and Technology Publishing House, 2018.

9. Ayupov R.Kh., Baltabaeva G.R. Problems and solutions for the formation of an innovative economy in Uzbekistan. Tashkent, Economy and Finance Publishing House, 2015.

10. Karimov, U. U. (2021). Scientific and Theoretical Foundations of the Formation of the Social Environment in the Family. Oriental Journal of Social Sciences, 37-40.

11. Бутабоев, М. Т., \& Каримов, У. У. (2020). ПЕРЕХОД К «ЗЕЛЁНОЙ ЭКОНОМИКЕ» И ОСОБЕННОСТИ ЕЁ РАЗВИТИЯ В УЗБЕКИСТАНЕ. Интернаука, 23(152 часть 2), 41.

12. Abdurakhmonova, M. M., ugli Mirzayev, M. A., Karimov, U. U., \& Karimova, G. Y. (2021). Information Culture And Ethical Education In The Globalization Century. The American Journal of Social Science and Education Innovations, 3(03), 384388.

13. Khasanov I. M. Essence, Mission And Value Of Enterpreneurship Activity //The American Journal of Management and Economics Innovations. - 2021. - T. 3. - №. 02. - C. 38-45.

14. Tobin, J. (1974). The New Economics One Decade Older. Princeton.

15. Azizov, O. (2021). Developing small business and entrepreneurship through the transition to the digital economy. ACADEMICIA: An International Multidisciplinary Research Journal, 11(4), 1132-1139.

16. Karimov, U., \& Abdurakhmon, A. (2017). 
The American Journal of Management and Economics Innovations

(ISSN - 2693-0811)

Published: August 31, 2021 | Pages: 9-14

IMPACT FACTOR

2021: 5.562

Doi: https://doi.org/10.37547/tajmei/Volume03Issue08-03

INNOVATIVE

INFORMATION

TECHNOLOGY IN EDUCATION. Форум молодых ученых, (5), 9-12.

17. Arzimatova, I. (2019). AESTHETIC EDUCATION, ITS FEATURES AND STRUCTURE. Scientific Bulletin of Namangan State University, 1(6), 219-222.

18. Khakimov N.H., Ganiyev B.S., THE ROLE OF STUDYING THE STRATEGY OF ACTION IN CHOOSING A PROFESSIONAL DIRECTION (TAKING INTO ACCOUNT THE FORMATION OF ENTREPRENEURIAL QUALITIES) IN STUDENTS // Scientific Bulletin of Namangan State University. Namangan, 2019. № 7 - P. 296-303.

19. TURSUN, S., TUYCHIEVICH, B. M., \& MUROTOVICH, M. F. Effects of the Global Crisis on the Economy of Uzbekistan During the Coronovirus Pandemidia and Measures to Ease IT. JournalNX, 6(05), 277-280.

20. Butaboev, M. T., \& Karimov, U. U. (2020). «ЗЕЛЁНАЯ ЭКОНОМИКА». МИРОВОЙ ОПЫТ И ОСОБЕННОСТИ РАЗВИТИЯ В УЗБЕКИСТАНЕ. Theoretical \& Applied Science, (2), 704-710.

21. Mulaydinov, F. (2021). Digital Economy Is $A$ Guarantee Of Government And Society Development. Ilkogretim Online, 20(3), 1474-1479.

22. Mulaydinov, F. M. (2019). Econometric Modelling of the Innovation Process in Uzbekistan. Форум молодых ученых, (3), 35-43.

23. Каримов, У. У. (2017). РОЛЬ СРЕДСТВ МАССОВОЙ ИНФОРМАЦИИ В ПРОЦЕССЕ ГЛОБАЛИЗАЦИИ. In Перспективные информационные технологии (ПИТ 2017) (рp. 1189-1192).

24. Farkhod, M. (2020). Econometric Modelling of the Innovation Process in
Uzbekistan. International Journal of Psychosocial Rehabilitation, 24(02).

25. Каримов, У. (2017). ИНФОКОМТЕХНОЛОГИИ (ИКТ) ФОРМИРОВАНИЕ ДУХОВНЫХ ХАРАКТЕРИСТИК ЛИЧНОСТИ. In Перспективные информационные технологии (ПИТ 2017) (рр. 1160-1163).

26. Suyumov, J., Madaliyeva, G., \& Xakimova, K. (2021). IMITATION MODELING TECHNOLOGIES IN HIGHER EDUCATIONAL PROCESS. Теория $и$ практика современной науки, (5), 18-21.

27. Arzimatova, I. M. (2020). SPIRITUAL CULTURE OF PERSONALITY AND ARTISTIC AND AESTHETIC CHANGES. Scientific Bulletin of Namangan State University, 2(11), 160-165.

28. Каримов, У., \& Каримова, Г. (2018). ГЕОПОЛИТИЧЕСКАЯ КОНКУРЕНЦИЯ В ИНФОРМАЦИОННОМ ПРОСТРАНСТВЕ. In Перспективные информационные технологии (ПИТ 2018) (рр. 1368-1372).

29. Bozarov, D. M., \& Karimova, G. Y. (2021). ROLE OF THE SELF-ORGANIZATION MODEL IN COMPLEX SOCIAL SYSTEMS. Oriental Journal of Social Sciences, 1-9.

30. Sayitkhonov A. THE IMPORTANCE OF INNOVATIVE ACTIVITIES OF YOUTH TO ENTREPRENEURSHIP //Theoretical \& Applied Science. - 2020. - №. 1. - C. 38-41.

31. Каримова, Г. Й. (2018). РОЛЬ КОНСТИТУЦИИ В ПОСТРОЕНИИ ПРАВОВОГО ГОСУДАРСТВА И ГРАЖДАНСКОГО ОБЩЕСТВА. Теория и практика современной науки, (2), 161163.

32. Пулатов, Г. Г., \& Мадалиева, Г. А. (2018). ИССЛЕДОВАНИЕ СВОЙСТВ КАУСТИК ПРИ ПОМОЩИ MAPLETS. In ИННОВАЦИОННОЕ РАЗВИТИЕ НАУКИ И 
ОБРАЗОВАНИЯ (рр. 30-32).

33. Pulatov, G., Ganiev, S., \& Karimova, G. POSSIBILITIES OF INFORMATION TECHNOLOGIES IN ENSURING THE QUALITY OF EDUCATION.

34. Karimov, U., \& Kasimov, I. (2018). THE IMPORTANCE OF MODERN INFORMATION TECHNOLOGIES IN DEVELOPMENT OF DISTANCE EDUCATION. In Перспективные информационные технологии (ПИТ 2018) (pp. 1186-1187).

35. Xasanov, I. M. (2019). Problems of employment in Uzbekistan. Образование и наука в России и за рубежом, (16), 156158.

36. Karimov A., Muxammadjonov $X$. INFORMATION TECHNOLOGIES: INFORMATION EDUCATION AND INFORMATICS //Экономика и социум. 2020. - №. 8. - C. 40-43. 